p-ISSN : 2597-8977

e-ISSN : 2597-8985

Muthmainna Dayanti Jufri*) Prodi Pendidikan IPA FMIPA Universitas Negeri Makassar

Ratnawaty Maming Prodi Pendidikan IPA FMIPA Universitas Negeri Makassar

Muhammad Aqil Rusli Prodi Pendidikan IPA FMIPA Universitas Negeri Makassar

\section{STUDI KETERAMPILAN BERPIKIR TINGKAT TINGGI PESERTA DIDIK KELAS IX SMPN DI KOTA MAKASSAR}

Abstrak: Penelitian ini bertujuan untuk : (1) mengetahui keterampilan berpikir kreatif peserta didik kelas IX SMPN di Kota Makassar, (2) mengetahui keterampilan berpikir kritis peserta didik kelas IX SMPN di Kota Makassar, (3) mengetahui keterampilan pemecahan masalah peserta didik kelas IX SMPN di Kota Makassar, dan (4) mengetahui keterampilan pengambilan keputusan peserta didik kelas IX SMPN di Kota Makassar. Penelitian ini merupakan penelitian survey dengan menggunakan desain penelitian survey deskriptif. Populasi dalam penelitian ini adalah seluruh peserta didik kelas IX SMPN yang terakreditasi di Kota Makassar sebanyak 9844. Pengambilan sampel secara Random Sampling Class menggunakan rumus slovin. Instrumen penelitian ini berupa tes kemampuan HOTS berbentuk soal pilihan ganda 33 item dan essay 9 item yang telah divalidasi ahli. Hasil penelitian ditemukan: (1) Keterampilan berpikir kreatif peserta didik kelas IX memiliki rata-rata skor keseluruhan 1,94 dimana skor ini berkategori sangat rendah, (2) Keterampilan berpikir kritis peserta didik kelas IX memiliki rata-rata skor keseluruhan 1,10 dimana skor ini berkategori sangat rendah, (3) Keterampilan pemecahan masalah peserta didik kelas IX memiliki rata-rata skor keseluruhan 6,15 dimana skor ini berkategori sangat rendah, (4) Keterampilan pengambilan keputusan peserta didik kelas IX memiliki rata-rata skor keseluruhan 5,11 dimana skor ini berkategori sangat rendah.

Kata Kunci: Keterampilan Berpikir Tingkat Tinggi, Keterampilan Berpikir Kreatif, Keterampilan Berpikir Kritis, Keterampilan Pemecahan Masalah, Keterampilan Pengambilan Keputusan.

Abstract: This study aims: (1) To know the creative thinking skills students grade IX junior high school in Makassar City, (2) To know the critical thinking skills students grade IX junior high school in Makassar City, (3) To know the problem solving skills students grade IX junior high school in Makassar City, and (4) To know the decision making skills students grade IX junior high school in Makassar City. This research is a survey research using descriptive survey research design. The population in this study were all grade IX students of junior high school who were accredited in Makassar City as much as 9844. Sampling uses Slovin formula and random sampling class. This research instrument was in the form of higher order thinking skills ability test in the form of 33 items multiple choice questions and 9 items essay that had been validated by experts. The results found: (1) Creative thinking skills of students grade IX have an average score of 1,94 where the score included in the very low category, (2) Critical thinking skills of students grade IX have an average score of 1,10 where the score is included in the very low category, (3) The problem solving skills of students grade IX have an average score of 6,15 where the score is included in the 
very low category, (4) The decision making skills students grade IX have an average score of 5,11 where the score is included in the very low category.

Keyword: Higher Order Thinking Skills, Creative Thinking Skills, Critical Thinking Skills, Problem Solving Skills, Decision Making Skills. 


\section{PENDAHULUAN}

Sekarang ini kita berada pada era globalisasi dan tuntutan Masyarakat Ekonomi Asean (MEA) oleh karena itu sebuah negara dituntut untuk memiliki kualitas Sumber Daya Manusia (SDM) yang berkualitas. Adapun salah satu faktor yang mempengaruhi kualitas SDM suatu Negara yaitu pendidikan. Sumber Daya Manusia (SDM) yang baik dan berkualitas yaitu memiliki pemikiran yang kritis, sistematis, logis, kreatif, dan kemauan untuk bekerja sama satu sama lain. SDM yang telah disebutkan di atas merupakan pemikiran yang didapatkan dari lembaga pendidikan sekolah.

Seperti yang kita ketahui dalam dunia pendidikan, Higher Order Thinking Skills (HOTS) merupakan hal yang penting diterapkan dalam pembelajaran. Pembelajaran HOTS bukan hanya sekedar menuntut peserta didik untuk hanya mengingat kemudian memahaminya. Akan tetapi, dengan adanya HOTS maka peserta didik mampu untuk berpikir dengan cara menganalisis suatu pembelajaran sampai pada tahap mencipta.

Apalagi standar yang dimiliki oleh HOTS saat ini sesuai dengan Standar Internasional seperti Organisasi untuk Kerja Sama dan Pembangunan Ekonomi (OECD), Trends in International Match and Science Survey (TIMMS), dan Programme for International Student Assessment (PISA), dengan diterapkannya HOTS dalam pembelajaran kemampuan peserta didik untuk menerapkan pengetahuan, keterampilan dan nilai sehingga dapat memecahkan suatu masalah dengan cara mengambil keputusan yang terarah serta mampu menciptakan sesuatu yang sifatnya inovatif.

Kecakapan yang dibutuhkan di Abad 21 juga merupakan keterampilan berpikir lebih tinggi yang sangat diperlukan dalam mempersiapkan peserta didik dalam menghadapi tantangan global. Dengan diterapkannya keterampilan berpikir tingkat tinggi peserta didik akan dapat menghubungkan, memanipulasi, dan mentransformasi pengetahuan serta pengalaman yang sudah dimiliki untuk berpikir secara kritis dan kreatif dalam upaya menentukan keputusan dan memecahkan masalah pada situasi baru.

Berdasarkan hasil penelitian dari beberapa peneliti tentang keterampilan berpikir tingkat tinggi. Dilihat dari hasil penelitian (Kurniati, Harimukti, \& Jamil, 2016) menunjukkan bahwa peserta didik yang memiliki kemampuan HOTS level sedang mampu mengidentifikasi ide utama, menganalisis argumen, dan menunjukkan kegunaan hal yang diketahui untuk menjawab beberapa soal, sehingga memiliki kemampuan analisis cukup baik, peserta didik yang memiliki kemampuan HOTS level rendah kurang mampu mengidentifikasi ide utama, menganalisa argumen, dan menunjukkan kegunaan hal yang diketahui untuk menjawab semua soal, sehingga memiliki kemampuan analisis kurang baik, sedangkan tidak adanya peserta didik yang memiliki kemampuan HOTS tinggi hal tersebut disebabkan karena peserta didik kurang mengerti terhadap beberapa materi dan kegunaannya dalam kehidupan sehari-hari.

Disamping itu, untuk menerapkan HOTS dalam pembelajaran maka yang perlu diperhatikan juga adalah kelayakan dari sebuah Satuan Pendidikan. Berdasarkan Permendikbud RI Nomor 13 Tahun 2018 Pasal 18, status Akreditasi Satuan Pendidikan terdiri atas dua, yaitu: terakreditasi dan tidak terakreditasi. Peringkat terakreditasi Satuan Pendidikan terdiri atas: terakreditasi A (unggul), terakreditasi B (baik), dan terakreditasi C (cukup). Sementara itu, jika kelayakan seluruh program yang diselenggarakan pada saat akreditasi tidak terpenuhi maka Satuan Pendidikan tersebut akan memiliki peringkat yang tidak terakreditasi.

Menurut Thomas \& Thorne (Nugroho, 2018) HOTS merupakan cara berpikir yang lebih tinggi daripada menghafalkan fakta, mengemukakan fakta, atau menerapkan peraturan, rumus, dan prosedur. HOTS mengharuskan kita melakukan sesuatu berdasarkan fakta. Membuat keterkaitan antar fakta, mengategorikannya, memanipulasinya, menempatkannya pada konteks atau cara yang baru, dan mampu menerapkannya untuk mecari solusi baru terhadap sebuah masalah. 
Untuk mewujudkan tercapaianya keterampilan berpikir tingkat tinggi, maka terdapat empat keterampilan berpikir yang harus dipenuhi, yaitu: keterampilan berpikir kreatif, keterampilan berpikir kritis, keterampilan pemecahan masalah, dan keterampilan pengambilan keputusan.

Menurut (Tawil \& Liliasari, 2013) ada empat aspek keterampilan berpikir kreatif, yakni:

1) Membangkitkan keiingintahuan dan hasrat ingin tahu

2) Membangun pengetahuan yang telah ada pada peserta didik

3) Memandang dari sudut pandang yang berbeda; dan

4) Meramal dari informasi yang terbatas.

Indikator keterampilan berpikir kritis dibagi menjadi 5 kelompok (Ennis, 1985) yaitu: memberikan penjelasan sederhana (elementary clarification), membangun keterampilan dasar (basic support), membuat inferensi (inferring), memberikan penjelasan lebih lanjut (advanced clarification), mengatur strategi dan taktik (strategies and tactics).

Menurut Sri, A (Tawil \& Liliasari, 2013), dalam menghadapi masalah yang lebih pelik manusia dapat menggunakan cara ilmiah. Indikator pemecahan masalah sebagai berikut: (1) memahami masalah; (2) mengumpulkan data; (3) merumuskan hipotesis (jawaban sementara yang mungkin memberi penyelesaian; (4) menilai hipotesis; (5) mengadakan eksperimen atau menguji hipotesis; (6) menyimpulkan.

Menurut (Tawil \& Liliasari, 2013) mengambil keputusan merupakan proses berpikir untuk mengidentifikasi dan memutuskan pilihan dari berbagai pilihan yang ada. Adapun indikator keterampilan pengambilan keputusan yaitu:

1) Membuat pertanyaan apa yang diputuskan.

2) Mengumpulkan informasi

3) Menentukan pilihan-pilihan

4) Daftar pro dan kontra

5) Membuat kesimpulan

\section{METODE}

Jenis penelitian yang digunakan adalah metode penelitian survey. Penelitian ini diarahkan untuk mengetahui keterampilan berpikir tingkat tinggi peserta didik pada pembelajaran IPA pada materi tentang gaya dan gerak. Penelitian dilaksanakan pada Semester Ganjil Tahun Pelajaran 2019/2020. Penelitian dilaksanakan di 21 SMPN terakreditasi di Kota Makassar.

Populasi dari penelitian ini adalah seluruh peserta didik kelas IX SMPN yang terakreditasi di Kota Makassar sebanyak 9844. Pengambilan sampel menggunakan rumus slovin dan pengambilan sampel secara Random Sampling Class. Instrumen yang digunakan dalam penelitian ini yaitu tes keterampilan berpikir tingkat tinggi IPA.

Data keterampilan berpikir tingkat tinggi peserta didik diperoleh melalui pemberian tes keterampilan berpikir kreatif, instrumen yang digunakan merupakan tipe soal dalam bentuk essay dengan jumlah soal sebanyak 4; tes keterampilan berpikir kritis, instrumen yang digunakan merupakan tipe soal dalam bentuk essay dengan jumlah soal sebanyak 5; tes keterampilan pemecahan masalah, instrumen yang digunakan merupakan tipe soal pilihan ganda dengan jumlah soal sebanyak 18 ; tes keterampilan pengambilan keputusan, instrumen yang digunakan merupakan tipe soal pilihan ganda dengan jumlah soal sebanyak 15. 
Dengan kriteria pengkategorian skor dapat dilihat pada tabel 1 berikut:

Tabel 1. Pedoman pengkategorian skor

\begin{tabular}{cc}
\hline Tingkat Penguasaan & Kriteria \\
\hline $14,4-16$ & Sangat Tinggi \\
$12,8-14,24$ & Tinggi \\
$11,2-12,64$ & Sedang \\
$9,6-11,04$ & Rendah \\
$<9,44$ & Sangat Rendah \\
\hline
\end{tabular}

Sementara itu, untuk kriteria pengkategorian skor per indikator dapat dilihat pada tabel 2 dan 3 berikut:

Tabel 2. Pedoman pengkategorian skor setiap indikator keterampilan berpikir kreatif dan keterampilan berpikir kritis

\begin{tabular}{cc}
\hline Tingkat Penguasaan & Kriteria \\
\hline $3,6 \leq x$ & Sangat Tinggi \\
$3 \leq x<3,6$ & Tinggi \\
$2 \leq x<3$ & Sedang \\
$1 \leq x<2$ & Rendah \\
$0 \leq x<1$ & Sangat Rendah \\
\hline & (Ratumanan \& Laurens, 2003)
\end{tabular}

Tabel 3. Pedoman pengkategorian skor setiap indikator keterampilan pemecahan masalah dan keterampilan pengambilan keputusan

\begin{tabular}{cc}
\hline Tingkat Penguasaan & Kriteria \\
\hline $2,97 \leq x$ & Sangat Tinggi \\
$1,98 \leq x<2,97$ & Tinggi \\
$0,99 \leq x<1,98$ & Rendah \\
$0 \leq x<0,99$ & Sangat Rendah \\
\hline & (Ratumanan \& Laurens, 2003)
\end{tabular}

Data yang diperoleh dari sampel penelitian ini berupa data kuantitatif. Hasil penelitian meliputi tes hasil keterampilan berpikir kreatif, keterampilan berpikir kritis, keterampilan pemecahan masalah, dan keterampilan pengambilan keputusan peserta didik yang diolah menggunakan teknik statistik deskriptif. Statistik deskriptif berfungsi untuk mendeskripsikan objek yang diteliti melalui data sampel.

\section{HASIL DAN PEMBAHASAN}

\section{Hasil}

Hasil analisis penelitian yang telah dilakukan terhadap peserta didik kelas IX SMPN terakreditasi di Kota Makassar dengan jumlah sampel 1295, data dikumpulkan melalui tes kemampuan keterampilan berpikir tingkat tinggi (pemecahan masalah, pengambilan keputusan, 
kreatif, dan kritis) yang telah dikerjakan oleh peserta didik, yang kemudian diberikan skor masingmasing item.

\section{a. Keterampilan berpikir kreatif}

Rata-rata skor keterampilan berpikir kreatif yaitu 1,94 dimana skor ini jika dilihat pada pengkategorian keterampilan berpikir kreatif pada Tabel 4 termasuk dalam kategori sangat rendah, sebagai berikut:

Tabel 4. Pengkategorian skor keterampilan berpikir kreatif

\begin{tabular}{ccc}
\hline Tingkat Penguasaan & Frekuensi & Kriteria \\
\hline $14,4-16$ & 0 & Sangat Tinggi \\
$12,8-14,24$ & 0 & Tinggi \\
$11,2-12,64$ & 0 & Sedang \\
$9,6-11,04$ & 2 & Rendah \\
$<9,44$ & 1293 & Sangat Rendah \\
\hline
\end{tabular}

Berdasarkan Tabel 5 rata-rata skor keterampilan berpikir kreatif yang diperoleh setiap indikator dari keseluruhan jumlah peserta didik yaitu (1) Membangkitkan keingintahuan dan hasrat ingin tahu sebesar 0,43 dimana skor tersebut termasuk dalam kategori sangat rendah. Dengan persentase 0,1\% kategori sangat tinggi, 0,30\% kategori tinggi, 3,1\% kategori sedang, 35,7\% kategori rendah, dan 60,8\% kategori sangat rendah; (2) Membangun pengetahuan yang telah ada pada peserta didik sebesar 0,80 dimana skor tersebut termasuk dalam kategori sangat rendah. Dengan persentase 3,4\% kategori sangat tinggi, 9,3\% kategori tinggi, 9,0\% kategori sedang, 21,4\% kategori rendah, dan 56,9\% kategori sangat rendah; (3) Memandang dari sudut pandang yang berbeda sebesar 0,31 dimana skor tersebut termasuk dalam kategori sangat rendah. Dengan persentase 0,1\% kategori sangat tinggi, 0,23\% kategori tinggi, 0,07\% kategori sedang, 30,3\% kategori rendah, dan 69,3\% kategori sangat rendah; (4) Meramal dari informasi yang terbatas sebesar 0,37 dimana skor tersebut termasuk dalam kategori sangat rendah. Dengan persentase 0,77\% kategori sangat tinggi, 0\% kategori tinggi, 4,1\% kategori sedang, 25,79\% kategori rendah, dan 69,34\% kategori sangat rendah.

Tabel 5. Pengkategorian skor keterampilan berpikir kreatif per indikator

\begin{tabular}{|c|c|c|c|c|c|c|c|c|c|c|}
\hline \multirow{3}{*}{ Indikator } & \multicolumn{10}{|c|}{ Tingkat Penguasaan } \\
\hline & \multicolumn{2}{|c|}{$\begin{array}{c}3,6 \leq \mathrm{x} \\
\text { (sangat tinggi) }\end{array}$} & \multicolumn{2}{|c|}{$\begin{array}{l}3 \leq x<3,6 \\
\text { (tinggi) }\end{array}$} & \multicolumn{2}{|c|}{$\begin{array}{c}2 \leq x<3 \\
\text { (sedang) }\end{array}$} & \multicolumn{2}{|c|}{$\begin{array}{c}1 \leq x<2 \\
\text { (rendah) }\end{array}$} & \multicolumn{2}{|c|}{$\begin{array}{c}0 \leq \mathrm{x}<1 \\
\text { (sangat rendah) }\end{array}$} \\
\hline & $f$ & $\%$ & $f$ & $\%$ & $f$ & $\%$ & $f$ & $\%$ & $f$ & $\%$ \\
\hline 1 & 2 & 0,1 & 4 & 0,30 & 40 & 3,1 & 462 & 35,7 & 787 & 60,8 \\
\hline 2 & 44 & 3,4 & 120 & 9,3 & 117 & 9,0 & 277 & 21,4 & 737 & 56,9 \\
\hline 3 & 2 & 0,1 & 3 & 0,23 & 1 & 0,07 & 392 & 30,3 & 897 & 69,3 \\
\hline 4 & 10 & 0,77 & 0 & 0 & 53 & 4,1 & 334 & 25,79 & 898 & 69,34 \\
\hline
\end{tabular}

Keterangan :

$1=$ membangkitkan keingintahuan dan hasrat ingin tahu

2 = membangun pengetahuan yang telah ada pada peserta didik

$3=$ memandang dari sudut pandang yang berbeda

$4=$ meramal dari informasi yang terbatas 


\section{b. Keterampilan berpikir kritis}

Rata-rata skor keterampilan berpikir kritis yaitu 1,10 dimana skor ini jika dilihat pada pengkategorian keterampilan berpikir kritis pada Tabel 6 termasuk dalam kategori sangat rendah, sebagai berikut:

Tabel 6. Pengkategorian skor keterampilan berpikir kritis

\begin{tabular}{ccc}
\hline Tingkat Penguasaan & Frekuensi & Kriteria \\
\hline $18-20$ & 0 & Sangat Tinggi \\
$16-17,8$ & 0 & Tinggi \\
$14-15,8$ & 0 & Sedang \\
$12-13,8$ & 0 & Rendah \\
$<11,8$ & 1295 & Sangat Rendah \\
\hline
\end{tabular}

Berdasarkan Tabel 7 rata-rata skor keterampilan berpikir kritis yang diperoleh setiap indikator dari keseluruhan jumlah peserta didik yaitu (1) Memberikan penjelasan sederhana sebesar 0,22 dimana skor tersebut termasuk dalam kategori sangat rendah. Dengan persentase $0 \%$ kategori sangat tinggi, $0 \%$ kategori tinggi, 0,1\% kategori sedang, 22,2\% kategori rendah, dan $77,7 \%$ kategori sangat rendah; (2) Membangun keterampilan dasar sebesar 0,25 dimana skor tersebut termasuk dalam kategori sangat rendah. Dengan persentase $0 \%$ kategori sangat tinggi, $0 \%$ kategori tinggi, 1,32\% kategori sedang, 23,24\% kategori rendah, dan 75,44\% kategori sangat rendah; (3) Membuat inferensi (menyimpulkan) sebesar 0,22 dimana skor tersebut termasuk dalam kategori sangat rendah. Dengan persentase $0 \%$ kategori sangat tinggi, 0,46\% kategori tinggi, 0,54\% kategori sedang, $20,1 \%$ kategori rendah, dan 78,9\% kategori sangat rendah; (4) Memberikan penjelasan lebih lanjut sebesar 0,19 dimana skor tersebut termasuk dalam kategori sangat rendah. Dengan persentase $0 \%$ kategori sangat tinggi, 0,30\% kategori tinggi, 5\% kategori sedang, 9,0\% kategori rendah, dan 85,7\% kategori sangat rendah; (5) Mengatur strategi dan taktik sebesar 0,20 dimana skor tersebut termasuk dalam kategori sangat rendah. Dengan persentase $0 \%$ kategori sangat tinggi, $0 \%$ kategori tinggi, 0,1\% kategori sedang, 19,9\% kategori rendah, 80\% kategori sangat rendah.

Tabel 7. Pengkategorian skor keterampilan berpikir kritis per indikator

\begin{tabular}{|c|c|c|c|c|c|c|c|c|c|c|}
\hline \multirow{3}{*}{ Indikator } & \multicolumn{10}{|c|}{ Tingkat Penguasaan } \\
\hline & \multicolumn{2}{|c|}{$\begin{array}{c}3,6 \leq x \\
\text { (sangat tinggi) }\end{array}$} & \multicolumn{2}{|c|}{$\begin{array}{c}3 \leq x<3,6 \\
\text { (tinggi) }\end{array}$} & \multicolumn{2}{|c|}{$\begin{array}{c}2 \leq \mathrm{x}<3 \\
\text { (sedang) }\end{array}$} & \multicolumn{2}{|c|}{$\begin{array}{c}1 \leq x<2 \\
\text { (rendah) }\end{array}$} & \multicolumn{2}{|c|}{$\begin{array}{c}0 \leq \mathrm{x}<1 \\
\text { (sangat rendah) }\end{array}$} \\
\hline & $f$ & $\%$ & $f$ & $\%$ & $f$ & $\%$ & $f$ & $\%$ & $f$ & $\%$ \\
\hline 1 & 0 & 0 & 0 & 0 & 2 & 0,1 & 287 & 22,2 & 1006 & 77,7 \\
\hline 2 & 0 & 0 & 0 & 0 & 17 & 1,32 & 301 & 23,24 & 977 & 75,44 \\
\hline 3 & 0 & 0 & 6 & 0,46 & 7 & 0,54 & 260 & 20,1 & 1022 & 78,9 \\
\hline 4 & 0 & 0 & 4 & 0,30 & 64 & 5 & 117 & 9,0 & 1110 & 85,7 \\
\hline 5 & 0 & 0 & 0 & 0 & 2 & 0,1 & 257 & 19,9 & 1036 & 80 \\
\hline
\end{tabular}

\section{Keterangan :}

$1=$ memberikan penjelasan sederhana

$2=$ membangun keterampilan dasar

$3=$ membuat inferensi (menyimpulkan)

$4=$ memberikan penjelasan lebih lanjut

$5=$ mengatur strategi dan taktik 


\section{c. Keterampilan pemecahan masalah}

Rata-rata skor keterampilan pemecahan masalah yaitu 6,15 dimana skor ini jika dilihat pada pengkategorian keterampilan pemecahan masalah pada Tabel 4.8 termasuk dalam kategori sangat rendah, sebagai berikut:

Tabel 8. Pengkategorian skor keterampilan pemecahan masalah

\begin{tabular}{ccc}
\hline Tingkat Penguasaan & Frekuensi & Kriteria \\
\hline $16,2-18$ & 0 & Sangat Tinggi \\
$14,4-16,02$ & 0 & Tinggi \\
$12,6-14,22$ & 1 & Sedang \\
$10,8-12,42$ & 27 & Rendah \\
$<10,62$ & 1267 & Sangat Rendah \\
\hline
\end{tabular}

Berdasarkan Tabel 9 rata-rata skor keterampilan pemecahan masalah yang diperoleh setiap indikator dari keseluruhan jumlah peserta didik yaitu (1) Memahami masalah sebesar 0,32 dimana skor tersebut termasuk dalam kategori sangat rendah. Dengan persentase 2,2\% kategori sangat tinggi, 22,7\% kategori tinggi, 45,0\% kategori rendah, 30,1\% kategori sangat rendah; (2) Mengumpulkan data sebesar 0,25 dimana skor tersebut termasuk dalam kategori sangat rendah. Dengan persentase 1,5\% kategori sangat tinggi, 14,1\% kategori tinggi, 43,0\% kategori rendah, dan 41,4\% kategori sangat rendah; (3) Merumuskan hipotesis sebesar 0,34 dimana skor tersebut termasuk dalam kategori sangat rendah. Dengan persentase 3,4\% kategori sangat tinggi, $24,5 \%$ kategori tinggi, 44,2\% kategori rendah, dan 27,9\% kategori sangat rendah; (4) Menilai hipotesis sebesar 0,32 dimana skor tersebut termasuk dalam kategori sangat rendah. Dengan persentase $2,4 \%$ kategori sangat tinggi, $21,77 \%$ kategori tinggi, 47,33\% kategori rendah, dan $28,5 \%$ kategori sangat rendah; (5) Mengadakan eksperimen atau menguji hipotesis sebesar 0,51 dimana skor tersebut termasuk dalam kategori sangat rendah. Dengan persentase 21,23\% kategori sangat tinggi, $31,5 \%$ kategori tinggi, 27,87\% kategori rendah, dan 19,4\% kategori sangat rendah; (6) Menyimpulkan sebesar 0,28 dimana skor tersebut termasuk dalam kategori sangat rendah. Dengan persentase 2,2\% kategori sangat tinggi, 16\% kategori tinggi, 48,5\% kategori rendah, dan 33,3\% kategori sangat rendah.

Tabel 9. Pengkategorian skor keterampilan pemecahan masalah per indikator

\begin{tabular}{|c|c|c|c|c|c|c|c|c|}
\hline \multirow{3}{*}{ Indikator } & \multicolumn{8}{|c|}{ Tingkat Penguasaan } \\
\hline & \multicolumn{2}{|c|}{$\begin{array}{c}2,97 \leq x \\
\text { (sangat tinggi) }\end{array}$} & \multicolumn{2}{|c|}{$\begin{array}{c}1,98 \leq x<2,97 \\
(\text { tinggi) }\end{array}$} & \multicolumn{2}{|c|}{$\begin{array}{c}0,99 \leq x<1,98 \\
\text { (rendah) }\end{array}$} & \multicolumn{2}{|c|}{$\begin{array}{c}0 \leq x<0,99 \\
\text { (sangat rendah) }\end{array}$} \\
\hline & $f$ & $\%$ & $f$ & $\%$ & $f$ & $\%$ & $f$ & $\%$ \\
\hline 1 & 28 & 2,2 & 294 & 22,7 & 583 & 45,0 & 390 & 30,1 \\
\hline 2 & 19 & 1,5 & 183 & 14,1 & 557 & 43,0 & 536 & 41,4 \\
\hline 3 & 44 & 3,4 & 318 & 24,5 & 572 & 44,2 & 361 & 27,9 \\
\hline 4 & 31 & 2,4 & 282 & 21,77 & 613 & 47,33 & 369 & 28,5 \\
\hline 5 & 275 & 21,23 & 408 & 31,5 & 361 & 27,87 & 251 & 19,4 \\
\hline 6 & 28 & 2,2 & 207 & 16 & 628 & 48,5 & 432 & 33,3 \\
\hline
\end{tabular}

Keterangan :

$1=$ memahami masalah

2 = mengumpulkan data

$3=$ merumuskan hipotesis

4 = menilai hipotesis

$5=$ mengadakan eksperimen atau menguji hipotesis

$6=$ menyimpulkan 


\section{d. Keterampilan pengambilan keputusan}

Rata-rata skor keterampilan pengambilan keputusan yaitu 5,11 dimana skor ini jika dilihat pada pengkategorian keterampilan pengambilan keputusan pada Tabel 10 termasuk dalam kategori sangat rendah, sebagai berikut:

Tabel 10. Pengkategorian skor keterampilan pengambilan keputusan

\begin{tabular}{ccc}
\hline Tingkat Penguasaan & Frekuensi & Kriteria \\
\hline $13,5-15$ & 0 & Sangat Tinggi \\
$12-13,35$ & 1 & Tinggi \\
$10,5-11,85$ & 11 & Sedang \\
$9-10,35$ & 110 & Rendah \\
$<8,85$ & 1173 & Sangat Rendah \\
\hline
\end{tabular}

Berdasarkan Tabel 11 rata-rata skor keterampilan pengambilan keputusan yang diperoleh setiap indikator dari keseluruhan jumlah peserta didik yaitu (1) Membuat pertanyaan apa yang diputuskan sebesar 0,32 dimana skor tersebut termasuk dalam kategori sangat rendah. Dengan persentase 9,65\% kategori sangat tinggi, 15,05\% kategori tinggi, 38,7\% katgori rendah, dan 36,60\% kategori sangat rendah; (2) Mengumpulkan informasi sebesar 0,31 dimana skor tersebut termasuk dalam kategori sangat rendah. Dengan pesentase 4,2\% kategori sangat tinggi, 21,4\% kategori tinggi, 39,6\% kategori rendah, dan 34,8\% kategori sangat rendah; (3) Menentukan pilihan-pilihan sebesar 0,39 dimana skor tersebut termasuk dalam kategori sangat rendah. Dengan persentase 8,6\% kategori sangat tinggi, 28,5\% kategori tinggi, 36,60\% kategori rendah, dan 26,3\% kategori sangat rendah; (4) Daftar pro dan kontra sebesar 0,28 dimana skor tersebut termasuk dalam kategori sangat rendah. Dengan persentase 2,5\% kategori sangat tinggi, $14 \%$ kategori tinggi, 50,8\% kategori rendah, dan 32,7\% kategori sangat rendah; (5) Membuat kesimpulan sebesar 0,37 dimana skor tersebut termasuk dalam kategori sangat rendah. Dengan persentase 9,4\% kategori sangat tinggi, $23,8 \%$ kategori tinggi, 37,5\% kategori rendah, dan 29,3\% kategori sangat rendah.

Tabel 11. Pengkategorian skor keterampilan pengambilan keputusan per indikator

\begin{tabular}{|c|c|c|c|c|c|c|c|c|}
\hline \multirow{3}{*}{ Indikator } & \multicolumn{8}{|c|}{ Tingkat Penguasaan } \\
\hline & \multicolumn{2}{|c|}{$\begin{array}{c}2,97 \leq x \\
\text { (sangat tinggi) }\end{array}$} & \multicolumn{2}{|c|}{$\begin{array}{c}1,98 \leq x<2,97 \\
\text { (tinggi) }\end{array}$} & \multicolumn{2}{|c|}{$\begin{array}{c}0,99 \leq x<1,98 \\
\text { (rendah) }\end{array}$} & \multicolumn{2}{|c|}{$\begin{array}{c}0 \leq x<0,99 \\
\text { (sangat rendah) }\end{array}$} \\
\hline & $f$ & $\%$ & $f$ & $\%$ & f & $\%$ & $f$ & $\%$ \\
\hline 1 & 125 & 9,65 & 195 & 15,05 & 501 & 38,7 & 474 & 36,60 \\
\hline 2 & 54 & 4,2 & 277 & 21,4 & 513 & 39,6 & 451 & 34,8 \\
\hline 3 & 112 & 8,6 & 369 & 28,5 & 474 & 36,60 & 340 & 26,3 \\
\hline 4 & 32 & 2,5 & 182 & 14 & 658 & 50,8 & 423 & 32,7 \\
\hline 5 & 122 & 9,4 & 308 & 23,8 & 485 & 37,5 & 380 & 29,3 \\
\hline
\end{tabular}

Keterangan :

1 = membuat pertanyaan apa yang diputuskan

2 = mengumpulkan informasi

$3=$ menentukan pilihan-pilihan

$4=$ daftar pro dan kontra

$5=$ membuat kesimpulan

\section{Pembahasan}

Berdasarkan hasil analisis data deskriptif dan pengkategorian menunjukkan bahwa perlu diketahui bahwa untuk mewujudkan keterampilan berpikir tingkat tinggi di SMPN Terakreditasi di 
Kota Makassar sebanyak 21 sekolah terdapat empat jenis keterampilan berpikir yang digunakan dalam penelitian ini, yaitu keterampilan pemecahan masalah, keterampilan pengambilan keputusan, keterampilan berpikir kreatif, dan keterampilan berpikir kritis.

\section{Keterampilan Berpikir Kreatif}

Rata-rata skor kreatif yang diperoleh dari keseluruhan jumlah peserta didik adalah sebesar 1,94 dimana skor tersebut termasuk dalam kategori sangat rendah. Hal tersebut berdasarkan skor keterampilan berpikir kreatif yang diperoleh setiap indikator dari keseluruhan jumlah peserta didik yaitu (1) Membangkitkan keingintahuan dan hasrat ingin tahu sebesar 0,43 dimana skor tersebut termasuk dalam kategori sangat rendah. Dengan persentase 0,1\% kategori sangat tinggi, $0,30 \%$ kategori tinggi, 3,1\% kategori sedang, 35,7\% kategori rendah, dan 60,8\% kategori sangat rendah; (2) Membangun pengetahuan yang telah ada pada peserta didik sebesar 0,80 dimana skor tersebut termasuk dalam kategori sangat rendah. Dengan persentase 3,4\% kategori sangat tinggi, 9,3\% kategori tinggi, 9,0\% kategori sedang, 21,4\% kategori rendah, dan 56,9\% kategori sangat rendah; (3) Memandang dari sudut pandang yang berbeda sebesar 0,31 dimana skor tersebut termasuk dalam kategori sangat rendah. Dengan persentase 0,1\% kategori sangat tinggi, 0,23\% kategori tinggi, 0,07\% kategori sedang, 30,3\% kategori rendah, dan 69,3\% kategori sangat rendah; (4) Meramal dari informasi yang terbatas sebesar 0,37 dimana skor tersebut termasuk dalam kategori sangat rendah. Dengan persentase $0,77 \%$ kategori sangat tinggi, $0 \%$ kategori tinggi, 4,1\% kategori sedang, $25,79 \%$ kategori rendah, dan 69,34\% kategori sangat rendah.

Berdasarkan hasil penelitian (Muliyani \& Kurniawan, 2014) profil kemampuan berpikir kreatif siswa secara keseluruhan memiliki kemampuan berpikir kreatif cukup baik, dalam aspek fluency terdapat $5 \%$ yang memiliki kemampuan berpikir dengan kategori tinggi, $80 \%$ dengan kategori sedang dan $15 \%$ dengan kategori rendah. Sedangkan dalam aspek flexibility terdapat $55 \%$ siswa dengan kategori sangat kreatif, 15\% kategori diatas rata-rata dan 30\% kategori rata-rata. Sedangkan dalam aspek originality terdapat $25 \%$ siswa dengan kategori sangat kreatif, $45 \%$ siswa diatas rata-rata dan 30\% siswa kategori rata-rata. Sedangkan dalam aspek elaboration, $0 \%$ siswa kategori istimewa dan sangat kreatif, 15\% siswa kategori sangat baik diatas rata-rata, 15\% siswa kategori diatas rata-rata dan $55 \%$ siswa kategori rata-rata.

\section{Keterampilan Berpikir Kritis}

Rata-rata skor kritis yang diperoleh dari keseluruhan jumlah peserta didik adalah sebesar 1,10 dimana skor tersebut termasuk dalam kategori sangat rendah. Hal tersebut berdasarkan ratarata skor keterampilan berpikir kritis yang diperoleh setiap indikator dari keseluruhan jumlah peserta didik yaitu (1) Memberikan penjelasan sederhana sebesar 0,22 dimana skor tersebut termasuk dalam kategori sangat rendah. Dengan persentase $0 \%$ kategori sangat tinggi, $0 \%$ kategori tinggi, 0,1\% kategori sedang, 22,2\% kategori rendah, dan 77,7\% kategori sangat rendah; (2) Membangun keterampilan dasar sebesar 0,25 dimana skor tersebut termasuk dalam kategori sangat rendah. Dengan persentase 0\% kategori sangat tinggi, 0\% kategori tinggi, 1,32\% kategori sedang, 23,24\% kategori rendah, dan 75,44\% kategori sangat rendah; (3) Membuat inferensi (menyimpulkan) sebesar 0,22 dimana skor tersebut termasuk dalam kategori sangat rendah. Dengan persentase $0 \%$ kategori sangat tinggi, 0,46\% kategori tinggi, 0,54\% kategori sedang, 20,1\% kategori rendah, dan 78,9\% kategori sangat rendah; (4) Memberikan penjelasan lebih lanjut sebesar 0,19 dimana skor tersebut termasuk dalam kategori sangat rendah. Dengan persentase $0 \%$ kategori sangat tinggi, 0,30\% kategori tinggi, 5\% kategori sedang, 9,0\% kategori rendah, dan 85,7\% kategori sangat rendah; (5) Mengatur strategi dan taktik sebesar 0,20 dimana skor tersebut termasuk dalam kategori sangat rendah. Dengan persentase 0\% kategori sangat tinggi, 0\% kategori tinggi, 0,1\% kategori sedang, 19,9\% kategori rendah, 80\% kategori sangat rendah.

Berdasarkan penelitian (Nafi'ah \& Prasetyo, 2015) penerapan pendekatan scientific pada proses pembelajaran di SMP Negeri 9 Magelang telah berjalan dengan baik pada tahapan 
mengamati, menanya, mencoba dan mengkomunikasikan akan tetapi kurang baik pada tahap menalar. Hasil penelitian menunjukkan berpikir kritis siswa tergolong baik dengam 3\% siswa memiliki pemikiran kritis yang tinggi, $88 \%$ siswa memiliki pemikiran kritis yang sedang dan $9 \%$ siswa memiliki pemikiran kritis yang rendah.

\section{Keterampilan Pemecahan Masalah}

Rata-rata skor pemecahan masalah yang diperoleh dari keseluruhan jumlah peserta didik adalah sebesar 6,15 dimana skor tersebut termasuk dalam kategori sangat rendah. Hal tersebut berdasarkan rata-rata skor keterampilan pemecahan masalah yang diperoleh setiap indikator dari keseluruhan jumlah peserta didik yaitu (1) Memahami masalah sebesar 0,32 dimana skor tersebut termasuk dalam kategori sangat rendah. Dengan persentase 2,2\% kategori sangat tinggi, 22,7\% kategori tinggi, 45,0\% kategori rendah, 30,1\% kategori sangat rendah; (2) Mengumpulkan data sebesar 0,25 dimana skor tersebut termasuk dalam kategori sangat rendah. Dengan persentase 1,5\% kategori sangat tinggi, 14,1\% kategori tinggi, 43,0\% kategori rendah, dan 41,4\% kategori sangat rendah; (3) Merumuskan hipotesis sebesar 0,34 dimana skor tersebut termasuk dalam kategori sangat rendah. Dengan persentase 3,4\% kategori sangat tinggi, 24,5\% kategori tinggi, 44,2\% kategori rendah, dan 27,9\% kategori sangat rendah; (4) Menilai hipotesis sebesar 0,32 dimana skor tersebut termasuk dalam kategori sangat rendah. Dengan persentase 2,4\% kategori sangat tinggi, 21,77\% kategori tinggi, 47,33\% kategori rendah, dan 28,5\% kategori sangat rendah; (5) Mengadakan eksperimen atau menguji hipotesis sebesar 0,51 dimana skor tersebut termasuk dalam kategori sangat rendah. Dengan persentase $21,23 \%$ kategori sangat tinggi, 31,5\% kategori tinggi, 27,87\% kategori rendah, dan 19,4\% kategori sangat rendah; (6) Menyimpulkan sebesar 0,28 dimana skor tersebut termasuk dalam kategori sangat rendah. Dengan persentase 2,2\% kategori sangat tinggi, $16 \%$ kategori tinggi, 48,5\% kategori rendah, dan 33,3\% kategori sangat rendah.

Sedangkan berdasarkan penelitian dan pembahasan (Utami \& Wutsqa, 2017), maka dapat disimpulkan bahwa Kemampuan pemecahan masalah siswa SMP Negeri di Kabupaten Ciamis berada pada kriteria rendah. Berdasarkan tahap polya, kemampuan pemecahan masalah pada tahap memahami masalah $49,41 \%$ berada pada kriteria sedang, tahap merencanakan pemecahan masalah 34,33\% berada pada kriteria rendah, tahap melaksanakan rencana masalah $42,14 \%$ berada pada tahap sedang dan tahap memeriksa kembali hasil 4,24\% berada pada kriteria sangat rendah.

Berdasarkan penelitian (Saidah \& Nurita, 2017) keterampilan pemecahan masalah IPA siswa SMP kelas VIII mengalami peningkatan yang dapat dilihat dari hasil uji analisis gain score ternormalisasi dan secara rata-rata mengalami peningkatan dengan kategori tinggi yaitu dengan skor 0,78 diketahui dari hasil nilai pre-test sebesar 25,25 dan post-test sebesar 82,18.

\section{Keterampilan Pengambilan Keputusan}

Rata-rata skor pengambilan keputusan yang diperoleh dari keseluruhan jumlah peserta didik adalah sebesar 5,11 dimana skor tersebut termasuk dalam kategori sangat rendah. Hal tersebut berdasarkan rata-rata skor keterampilan pengambilan keputusan yang diperoleh setiap indikator dari keseluruhan jumlah peserta didik yaitu (1) Membuat pertanyaan apa yang diputuskan sebesar 0,32 dimana skor tersebut termasuk dalam kategori sangat rendah. Dengan persentase 9,65\% kategori sangat tinggi, 15,05\% kategori tinggi, 38,7\% katgori rendah, dan 36,60\% kategori sangat rendah; (2) Mengumpulkan informasi sebesar 0,31 dimana skor tersebut termasuk dalam kategori sangat rendah. Dengan pesentase 4,2\% kategori sangat tinggi, 21,4\% kategori tinggi, 39,6\% kategori rendah, dan 34,8\% kategori sangat rendah; (3) Menentukan pilihan-pilihan sebesar 0,39 dimana skor tersebut termasuk dalam kategori sangat rendah. Dengan persentase $8,6 \%$ kategori sangat tinggi, 28,5\% kategori tinggi, 36,60\% kategori rendah, dan 26,3\% kategori sangat rendah; (4) Daftar pro dan kontra sebesar 0,28 dimana skor tersebut termasuk dalam kategori sangat rendah. Dengan persentase 2,5\% kategori sangat tinggi, 14\% kategori tinggi, 50,8\% kategori rendah, dan $32,7 \%$ kategori sangat rendah; (5) Membuat kesimpulan sebesar 0,37 dimana skor tersebut 
termasuk dalam kategori sangat rendah. Dengan persentase 9,4\% kategori sangat tinggi, 23,8\% kategori tinggi, 37,5\% kategori rendah, dan 29,3\% kategori sangat rendah.

Berdasarkan hasil penelitian yang dilakukan oleh (Badarudin, 2017) mengenai keterampilan pengambilan keputusan yaitu terdapat perbedaan peningkatan keterampilan pengambilan keputusan antara siswa.

\section{KESIMPULAN}

Berdasarkan hasil penelitian yang dilakukan mengenai studi keterampilan berpikir tingkat tinggi peserta didik kelas IX SMPN di Kota Makassar, disimpulkan bahwa:

1. Keterampilan berpikir kreatif peserta didik kelas IX memiliki rata-rata skor keseluruhan 1,94 dimana skor ini masuk ke dalam kategori sangat rendah.

2. Keterampilan berpikir kritis peserta didik kelas IX memiliki rata-rata skor 1,10 dimana skor ini masuk ke dalam kategori sangat rendah.

3. Keterampilan pemecahan masalah peserta didik kelas IX memiliki rata-rata skor 6,15 dimana skor ini masuk ke dalam kategori sangat rendah.

4. Keterampilan pengambilan keputusan peserta didik kelas IX memiliki rata-rata skor 5,11 dimana skor ini masuk ke dalam kategori sangat rendah.

\section{DAFTAR PUSTAKA}

Arifin, Z. (2014). Evaluasi Pembelajaran (Prinsip, Teknik, Prosedur). Bandung: PT Remaja Rosdakarya.

Badarudin. (2017). Peningkatan Keterampilan Pengambilan Keputusan dan Penguasaan Konsep IPA Melalui Model Pembelajaran Advance Organizer di Sekolah Dasar. Pendidikan Dasar.

Kurniati, D., Harimukti, R., \& Jamil, N. A. (2016). Kemampuan Berpikir Tingkat Tinggi Siswa SMP di Kabupaten Jember dalam Menyelesaikan Soal Berstandar PISA. Jurnal Penelitian dan Evaluasi Pendidikan.

Muliyani, R., \& Kurniawan, Y. (2014). Profil Kemampuan Berpikir Kreatif dan Peningkatan Hasil Belajar Kognitif Siswa SMP Melalui Model Pembelajaran Kooperatif Tipe STAD. Pendidikan Fisika.

Nafi'ah, I., \& Prasetyo, A. P. (2015). Analisis Kebiasaan Berpikir Kritis Siswa Saat Pembelajaran IPA Kurikulum 2013 Berpendekatan Scientific. Unnes Journal of Biology Education.

Nugroho, R. A. (2018). HOTS (Kemampuan Berpikir Tingkat Tinggi: Konsep, Pembelajaran, Penilaian, dan Soal-soal). Jakarta: Grasindo.

Ratumanan, T. G., \& Laurens, T. (2003). Evaluasi Hasil Belajar yang Relevan dengan Kurikulum Berbasis Kompetensi. Surabaya: YP3IT.

Utami, R. W., \& Wutsqa, D. U. (2017). Analisis Kemampuan Pemecahan Masalah Matematika dan SelfEfficacy Siswa. Jurnal Riset Pendidikan Matematika.

Tawil, M., \& Liliasari. (2013). Berpikir Kompleks dan Implementasinya dalam Pembelajaran IPA. Makassar: Badan Penerbit UNM. 


\section{Muthmainna Dayanti Jufri}

Mahasiswa Program Studi Pendidikan IPA FMIPA UNM, aktif melakukan penelitian pada bidang Pendidikan IPA, dapat dihubungi melalui email: iinmuthmainna@gmail.com.

\section{Ratnawaty Maming}

Dosen Program Studi Pendidikan IPA FMIPA UNM, aktif melakukan penelitian pada bidang Pendidikan IPA, dapat dihubungi melalui email: ratnawatymaming@gmail.com.

\section{Muhammad Aqil Rusli}

Dosen Program Studi Pendidikan IPA FMIPA UNM, aktif melakukan penelitian pada bidang Pendidikan IPA, dapat dihubungi melalui email: m.aqilrusli@gmail.com. 